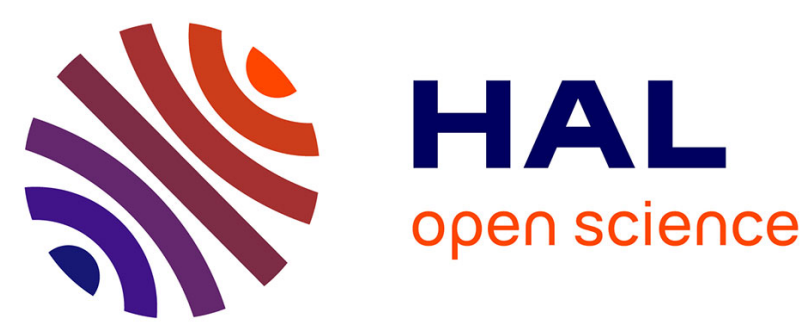

\title{
A NEW PHYSICO-CHEMICAL ASPECT IN ORGANIC PIEZOCHEMISTRY, HIGH PRESSURE SYNTHESIS INVOLVING CONGESTIONED SYSTEMS
}

\author{
G. Jenner
}

\section{To cite this version:}

G. Jenner. A NEW PHYSICO-CHEMICAL ASPECT IN ORGANIC PIEZOCHEMISTRY, HIGH PRESSURE SYNTHESIS INVOLVING CONGESTIONED SYSTEMS. Journal de Physique Colloques, 1984, 45 (C8), pp.C8-341-C8-343. 10.1051/jphyscol:1984861 . jpa-00224363

HAL Id: jpa-00224363 https://hal.science/jpa-00224363

Submitted on 1 Jan 1984

HAL is a multi-disciplinary open access archive for the deposit and dissemination of scientific research documents, whether they are published or not. The documents may come from teaching and research institutions in France or abroad, or from public or private research centers.
L'archive ouverte pluridisciplinaire HAL, est destinée au dépôt et à la diffusion de documents scientifiques de niveau recherche, publiés ou non, émanant des établissements d'enseignement et de recherche français ou étrangers, des laboratoires publics ou privés. 


\title{
A NEW PHYSICO-CHEMICAL ASPECT IN ORGANIC PIEZOCHEMISTRY .
} HIGH PRESSURE SYNTHESIS INVOLVING CONGESTIONED SYSTEMS

\author{
G. Jenner
}

Iaboratoire de Piézochimie Organique ${ }^{+}$, E.N.S.C., Université Louis Pasteur, 1, me Blaise Pascal, 67008 Strasbourg, France

Résumé - Le nouveau concept de volume d'activation liè à un état contraint permet d'expliquer l'effet accelerateur de la pression dans les réactions affectees par des contraintes géométriques (contraintes stériques, de tension, de torsion...). Dans ces réactions, l'effet cie contrainte a tendance à déplacer l'état de transition vers le produit en vertu du postulat de Hammond. Les conséquences synthétiques sont mises en lumière.

Abstract - The new concept of volume of activation related to a strained state is a reasonable explanation of the accelerating effect of pressure in reactions involving geometrical and conformational strain (steric, tension, torsional strain...). In such reactions, the strain effect shifts the transition state toward the product by virtue of the Hammond postulate. Synthetic applications of the concept are given.

\section{1. - INTRODUCTION}

The success of high pressure syntheses in liquid phase is intimately dependent on the value of the volume of activation $\Delta V^{\prime}$. The "later" or more "product-like" the transition state, the more pressure-accelerated the reaction rate. Stated in other words, if the transition state shifts far toward the final state, then pressure may be a determining parameter in achieving syntheses which would otherwise occur only hardly if not at all.

One possibility to create high negative volumes of activation is to apply high pressure on systems involving very compressive groups or considerable strain in the transition state $11 \%$. The object of this contribution is to consider this important piezochemical phenomenon.

\section{2. - PRESSURE EFFECT ON CONGESTIONED SYSTEMS}

Some twenty years ago, Gonikberg $/ 2 /$ found a strong pressure acceleration effect in Menshutkin reactions when comparing reaction rates for crowded 2,5-disubstituted pyridines vs. unhindered ones. Since the size of groups substituting the reaction centers involves conformational and geometric concepts, one may associate the pressure parameter. As a matter of fact, steric effects are large when adjacent parts of molecules are forced into close neighbourhood by rigid groups and the possibility of evasion are reduced to a minimum; this should have an effect on the volume of activation. Former studies from our laboratory /1,3/ have shown how steric demands of substituents and enhanced strain energy are measurable as activation volume components. Unless other effects (polarity or resonance) act in the opposite way, steric congestion produces "Late" transition states, justifying the use of very high pressures to overcome steric inhibition to reaction.

The volume of activation is actually a complex quantity and one may distinguish two essential kinds of volume contributions for a non-polar reaction :

- those generated by the establishment of the activated complex

\footnotetext{
+ UA CNRS 469
} 
- those related to the specific structure of the transition state (e.g. the volume modifications created within the transition state).

The former volume contributions act on the position of the transition state, while the latter do not. Considering strained transition states, we are interested in knowing what kind of volume changes will be involved in a strained or a hindered reaction compared to an unhindered standard.

Let us consider the additional volume components and formulate the overall volume of activation as a sum :

$$
\Delta v^{\neq}=\Delta v_{0}^{\neq}+\Sigma \Delta v_{z}^{\neq}
$$

$\Delta V^{\neq}$is the volume of activation of the standard reaction, $\Delta V_{z}^{\neq}$is a volume of activation relative to strain (steric, ring, ...), since a strained state may originate not only from bulkiness considerations, but also from ring strain, deformation, torsion, etc... In the case of steric strain $\left(\Delta v_{z}^{\neq}=\Delta v_{\sigma}^{\neq}\right), \Delta v_{\sigma}^{\neq}$was approximated as $11 /:$ :
$\Delta v_{\sigma}^{\neq}=-\omega \psi$ where $\omega$ is a substitution parameter (depending on the mode and the degree of substitution) and $\psi_{\sigma}$ a steric parameter representing the total value of the individual steric effects exerted by each substituent.

The concept of sieric volume of activation has been extended for ring strain /4/ with an additional volume term $\Delta V_{\tau}^{F}$ :

$$
\Delta v^{\neq}=\Delta v_{\sigma}^{\neq}+\Delta v_{\sigma}^{\neq}+\Delta v_{\tau}^{\neq}
$$

Thus the pure structural component in the formulation of the volume of activation may reflect the steric effects operating in the transition state. The additional volume contributions $\Delta V_{\sigma}^{\neq}, \Delta v_{\tau}^{\neq}$are dynamic terms, e.g. When the steric demand of the reaction increases, the transition state shifts gradually toward the product along the reaction coordinate. An important consequence of this phenomenon is its application to organic synthesis, since high pressure synthesis of crowded molecules is more accelerated with stronger steric interactions, due to the existence of $\Delta v_{z}^{*}$.

\section{3. - SYNTHETIC APPLICATIONS}

Some recent relevant investigations in this field are listed in table I just as illustrations. They concern reactions which occur only at high pressures $\left(500-1200 \mathrm{MPa}, 20-100^{\circ} \mathrm{C}\right)$.

Entries 1 and 2 describe the high pressure quaternization reaction of sterically hindered alcaloids. The addition of $\mathrm{CS}_{2}$ to norbornene (entry 3 ) is an example of a strained system imposed by ring strain. At high pressure reaction occurs, leading to an unusual adduct. This reaction should be compared to the high pressure addition of $\mathrm{CS}_{2}$ to the very strained quadricyclane molecule (entry 4) which yields another type of adduct (thietane). The hydroboration reactions involving olefins substituted by compressive groups (entry 5) reveal that high pressures promote the formation of trialkylborane, whereas at atmospheric pressure, usually the monoborane is alone formed.

The last example (entry 6 ) is provided by the addition of o-silylated ketene acetals to enones $19 / \mathrm{R}=\mathrm{Si}(\mathrm{Me})_{2}(\mathrm{tBu})$. There is a dramatic pressure effect on such sterically hindered addition.

In conclusion, the results demonstratethe utility of the pressure variable offering an exceptional mild strategy for obtaining new compounds by accelerating sluggish bond-forming reactions on sterically crowded or strained substrates. 
Table I

High pressure synthesis involving strained or congestioned systems

$\underset{\text { Entry }}{\text { Reaction }}$

\section{REFERENCES}

1 JENNER G. and KELLOU M., Tetrahedron 37 (1981) 1153.

2 GONIKBERG M.G., ZHULIN V. and ELYAINOV B., the Physics and chemistry of High Pressures, Soc. Chem. Ind. (London) (1963) 212.

3 JeNNER G. and KELLOU M., J. Chem. SOc., Chem. Comm. (1979) 851.

4 JENNER G., KELLOU M. and PAPADOPOULOS M., Angew. Chem. int. ed. 21 (1983) 363.

5 JURCZAK J., TKACZ i. and MAJCHRZAK-KUCZYNSKA U, J. Chem. Soc,, Chem. Comm. (1983) 920.

6 PETERMANN J. and PLIENINGER H., Tetrahedron 31 (1975) 1209.

7 JENNER G. and PAPADOPOULOS M., Tetrahedron Letters in press.

8 RICE J.E. and OKAMOTO Y., J. Org. Chem. 47 (1982) 4189.

9 BUNCE R.A., SCHLECHT M.F., DAUBEN W.G. and HEATHCOCK C.H., Tetrahedron Letters (1983) 4943. 